\title{
The Effect of Ease of Shopping, Online Customer Reviews and Maslahah Perceptions on Gen Z Online Shopping Decisions (Case Study Of UINSI and UMKT Samarinda Students)
}

\author{
Rogaina Rogaina ${ }^{1 *}$, Tikawati Tikawati $^{1}$, Anwaril Hamidy ${ }^{1}$ \\ ${ }^{1}$ Faculty Economic and Islamic Business, Sultan Aji Muhammad Idris Islamic University, Samarinda, \\ Indonesia
}

\begin{abstract}
This study aims to examine and analyse the effect of ease of shopping, online customer reviews and perceptions of maslahah on online shopping decisions among UINSI and UMKT Samarinda students. The type of research used is field research. The sample in this study was 198 people who had shopped online. The method of collecting data is a questionnaire is distributed online using Google form. Data analysis used multiple regression analysis. The results showed that of the three variables of ease of shopping, online customer review and perception of maslahah simultaneously affect online shopping decisions. From the calculation of SPSS 23. For the Ftest, it is known that $F_{\text {count }}=187.146>F_{\text {table }} 2.65$ with a significance of $0.000<0.5$. Partially, it is known that the ease of shopping, online customer reviews and the perception of maslahah have a significant effect of online shopping decisions. In addition to the Ftest and t-test, the $\mathrm{R}^{2}$ test is known to have an $\mathrm{R}$ square value of 0.743 which means the magnitude of the independent variable $74.3 \%$.
\end{abstract}

\section{Introduction}

Technology is growing with the time. With technology, everything you do is easier and efficient. Sophisticated technology makes things far closer, something difficult feels easier (Ardyanto, Heru Susilo, 2015). Progress technology has created new opportunities for online businesses. Consumer can anytime and anywhere without face to face (Rose et al., 2011). The existence of information technology is able to alleviate or solve problems, an obstacle or inability to achieve something.

Since the outbreak of the pandemic, people temd to increasingly choose to online shopping in order to reduce activities outside the home and make transactions directly. Online buying and selling makes economic agents more efficient in running their business and meeting their needs. Distance and time are not problem. The convenience of this technology is felt by consumers, which makes consumers no longer need to leave the house to transact, and consumers save time and effort without the need to find the product they

* Corresponding author: tika.ilir@gmail.com 


\section{AIC $\overline{I E B}$ Annual International Conference \\ on Islamic Economics and Business, 2021}

need. This style of shopping is growing rapidly with the proliferation of online or ecommerce markets and the increasing reach of the internet (Fernandes et al., 2021). The most significant changes in consumer behaviour include online shopping attitudes, door-todoor delivery and use contactless payments (WiScicka-Fernando, 2021). There are many choices of payment methods that can be done such as COD (Cash on Delivery) or pay when the products have arrived at the consumer, transfer via m-banking, use e-money, pay through the nearest supermarket, and consumers don't have to bother paying directly to the seller. Ease of payment and use affects the decision to shop online in the community, especially for students who do not have time to go out looking for the products they need. Therefore, it is suspected that convenience is one of the factors that influence online shopping decisions.

This is reinforced by the research conducted by Hamni Fadlillah Nasution in the Jurnal Ilmu Manajemen dan Bisnis Islam in 2018 with the title "The Influence of Ease and Price on Online Purchase Decisions for Clothing Products" with the research has the result that convenience influences the decision to buy clothes online (Nasution, 2018).

On the other hand, online shopping has a high risk such as goods that may be damaged in shipping, fraud that occurs when consumers have transferred money but the products are not delivered to consumers, the possibility of products purchased is not as expected, prices are more expensive from the store and various other risks. Because of the the possible risks, most potential customers will usually seek information in the form of reviews related to the product to be purchased to minimize the negative impact that may occur will be obtained by potential consumers. In online reviews, consumer recommendations are an important indicator for service providers to improve their consumer policies as well as their service quality (Jain et al., 2021). Trust by reviews or ratings made by buyers has an effect on buying decision. Among the forms of the review are online reviews through social media which have a fast and strong influence in influencing consumers. Reviews are able to help potential consumers in making purchase decisions. Thus, online customer reviews are thought to have an influence on online shopping decisions. This is supported by research by Yofina Mulyati and Grace Gesitera in the Jurnal Maksipreneur with the title "The Influence of Online Customer Reviews on Purchase Intentions with Trust as Intervening at Bukalapak's Online Store in Padang". Based on the results of these studies, the results obtained that online customer reviews provide positive and significant influence on online shopping intention through consumer trust (Mulyati \& Gesitera, 2020).

In addition to reasons of the reasons of the convenience and customers, some people also choose to shop online for reasons of how important and useful the product to be purchased. Online shopping makes consumption easier. This can lead to more suffiencyoriented goods and services purchased, but also comes with the risk of overconsumption (Frick \& Matthies, 2020). As a country where the majority of the population is Muslim, of course Muslim customers also want to get the benefits and blessings of the products the buy simultaneously (maslahah), by shopping according to their needs, not desires and not excessively. Achieving the maximum maslahah and avoiding mafsadah is the goal of Islamic law (maqashid sharia), which is also the goal of economic activity. Therefore, it is strongly suspected that the perception of maslahah is one of the things that influence decisions for the Muslims. This is supported by research conducted by Rini Elvira in 2016 in Jurnal Manhaj entitled "The Influence of Muslim Consumer Perceptions about Maslahah on Consumption Decisions Limited to Halal Commodities Only" with a case study on students of the Faculty of Sharia and Islamic Economics in 2015. The results of this research is the perception of Muslim consumers about maslahah giving an influence on the variable consumption decisions is limited only to halal commodities (Elvira, 2016).

In the realm of Islamic teachings and values, it is forbidden to harm oneself and others, as well as misuse property for useless purposes. Islam provides guidelines for consumption 


\section{$A I \overline{C E B} \quad$ Annual International Conference \\ on Islamic Economics and Business, 2021}

activities that are allowed and not allowed. However, today's society ignores sharia rules and continues to carry out unhealthy buying behaviour such as buying without thinking or planning properly (impulsive buying behavior) (Ahmad Musadik \& Abdul Ghani Azmi, 2019).

From the explanation above, this research is entitled The Effect of Ease of Shopping, Online Customer Review and maslahah Perceptions on Gen Z Online Shopping Decisions (Case Study of UINSI and UMKT Samarinda Students) which was conducted to seek clearer and more detailed information, as well as scientific evidence of the influence of convenience, online customer review, and maslahah perceptions with online decisions. Students are chosen because they are part of society closest to the problem of accessing information and the internet, and generally students doing online shopping as well as students from UINSI and UMKT Samarinda. UINSI students are taught courses with Islamic consumption and UMKT Samarinda also learns about the importance of shopping as needed so that it is not redundant and feels the benefits and blessings of what is consumed.

However, there is a research gap that is the result of previous studies that have been done. Different research results show a research gap on the influence of convenience and online customer review on online shopping decisions. The results of the study can be seen in Table 1 below:

Table 1. results of the study

\begin{tabular}{|c|c|c|}
\hline Variable relationship & Have influence & Have no influence \\
\hline $\begin{array}{l}\text { Ease of shopping on online } \\
\text { shopping decisions }\end{array}$ & $\begin{array}{ll}\text { 1. } & \text { Hamni Fadlilah Nasutin } \\
& (2018) \\
\text { 2. } & \text { Inas Rafidah dan Djawoto } \\
& (2017) \\
\end{array}$ & $\begin{array}{l}\text { 1. Eko Yuliawan, Hanny } \\
\text { Siagian Liangdy Willis } \\
(2018)\end{array}$ \\
\hline $\begin{array}{l}\text { Online customer review on } \\
\text { online shopping decisions }\end{array}$ & 1. $\quad$ Nuri purwanto (2019) & $\begin{array}{lll}\text { 2. } & \text { Ahmad Farki, } & \text { Imam } \\
& \text { Baihaqi, Berto } & \text { Mulia } \\
\text { Wibawa (2018) } & \\
\end{array}$ \\
\hline $\begin{array}{l}\text { Perception of maslahah } \\
\text { (usefulness) on online shopping } \\
\text { decisions }\end{array}$ & $\begin{array}{llr}1 . & \begin{array}{l}\text { Renny, } \\
\text { Hotniar }\end{array} & \text { Suryo } \\
(2013) & \text { Siringoringo }\end{array}$ & \\
\hline
\end{tabular}

The table shows that the results of research on the influence of ease of shopping, online customer review and mashlahah perception of online shopping decisions, there are differences in research, on the one hand some researchers stated an effect, but on the other hand had no effect.

\section{Literature Review}

\subsection{Consumer Behavior}

Consumer behaviour is a process that is closely related to the exixtence of a buying process, consumers usually carry out activities such as searching, researching, and evaluating products and services. When choosing to make a purchase, consumer usually think about the product to be purchased. Starting from the price, model, shape, packaging, quality, function or product benefits and so on (Firmansyah, 2019). According to Kotler and Armstrong in Meithiana Indrasari, the factors that influence consumer behaviour are cultural factors, social factors, personal factors, and phsychological factors (Indrasari, 2019). 


\section{$A I C \overline{C E B} \quad$ Annual International Conference \\ on Islamic Economics and Business, 2021}

\subsection{Ease of Shopping}

Davis provides a definition of ease of use as a degree to which a person believes that technology can be understood and used (Davis, 1989). Consumers value products and services that save time and simplify activities. It is estimated that online shopping is an attractive choice for consumers because it has advantages compared to regular shopping because it requires less energy, saves time and can be doneat any time and it will all be done with transaction security (Yuswohady, 2012).

The convenience referred to in this study is the ease of use and transactions made when shopping online. So that consumers do not need to come directly to the store to buy the products they need.

Ease of shopping online provides a change in people's shopping habits related to convenience. Ease of use and uncomplicated transactions. Perceived ease leads to the user's belief that using a particular system is without difficulty and effort. According Davis (Davis, 1989) convenience has several indicators, namely: information technology is easy to learn, information technology does easily what its user want, the user's skill will increase when using information technology, information technology is easy to operate, and users do not have to waste a lot of time.

\subsection{Online Customer Review}

Online customer review is an evaluation for a product that is produced by a company or third party. Electronic word of mouth (e-WOM) is another term for online-based customer reviews used by consumers. eWOM is also defined as a potentially postitive or negative statement made by individuals who are about to buy product, people who have ppurchased the product or service the company (Darics, 2016). Makes it easy for consumers to make comparisons with similar products by other online sellers. This is because of the benefits that digital marketing provides to consumers, so that consumers can transact without having to visit seller directly. Online customer review has several indicators namely (Darics, 2016): source credibility, argument quality, perceived usefulness, review valence, and quantity of review.

\subsection{Maslahah}

Maslahah literally means "something that brings goodness/ actions that encourage human goodness". In a general sense, maslahah means something that is beneficial to humans, either in the sense of attracting or producing such as generating profits and peace, or means fighting harm or damage. So, everything that is useful should be called maslahah (Dr. Moh. Mufid, Lc., 2018).

In Islamic economic theory, the consumer's goal is to get a benefit. Consumption activities for Muslim consumers are a way to achieve maslahah which is the goal of Islamic law. The reason why maslahah is used of human assumptions with the aim of seeking maximum satisfaction or utility cannot explain whether the item that provides satisfaction or utility cannot explain whether the item that provides satisfaction is always equivalent to the usefulness or blessing obtained by the user. In addition, a person's limits on consumption are only based on budgetary capabilities, and ignore the rules principles (Frida, 2020).

The purpose of consumption such as shopping in Islam is not merely to meet needs, but also to realize maslahah, by not consuming excessively and adjusting to needs not wants. 


\section{$A \mathrm{I} \overline{I E B} \quad$ Annual International Conference \\ on Islamic Economics and Business, 2021}

\subsection{Online Shopping}

Online shopping is an activity which is a communication that does not require direct (faceto-face) communication, it can be done separately from and to the rest of the world through computer media or mobile phones connected to the internet (Y.B., 2010). The use of internet facilities is a technological advancement that support all commercial activities.

\subsection{Online Shopping Decisions}

The decisions-making process for shopping will be determined by consumer behaviour. Decision is an activity that is carried out by everyone, in all situations, times and places. The consumer's decision to online shopping is an activity that is carried out consciously, rationally and planned. The shopping decision can be interpreted as a decision that carried out by consumers in buying products on the basis of their intention to make purchase (Adam, 2018).

In any process, Allah forbids his people in loss, as well as by shopping. Humans must be able to distinguish between needs and desires. Asy-Syatibi formulates human needs in Islam into 3 (three) levels (Chalil, 2009), namely: Dharruriyat needs (the level of needs that must exist or primary need ), Hajiyyat's needs are secondary need, and Tahsiniyyat needs or also tertiary needs which if not fulfilled do not threaten safety and do not trigger difficulties.

\section{Method}

This study applies a quantitative research type, because the data on ease of shopping, online customer review, perception of maslahah, and online shopping decisions will be processed and explained by collecting numerical data which is analysed using statistical-based methods.

This study also applies the type of associative research to determine the relationship between the variables of ease of shopping (X1), online customer review (X2), and perception of maslahah (X3) on the online shopping decision (Y). this research is also field research type, because the researcher takes data directly with the research subject.

The data used in this study is primary data which was directly collected by the data researcher and obtained from questionnaires distributes to UINSI and UMKT students. Using a Likert scale measurement, namely $1=$ strongly disagree, $2=$ disagree, $3=$ slightly disagree, 4 = agree, $5=$ strongly agree.

\section{Results and discussion}

\subsection{Validity Test}

The validity test is carried out using the SPSS 23 application. This validity test usingn a sample of 198 respondents (n) with a significance value of 0.05 with a 2 -sided test and $\mathrm{df}=$ $n-2(198-2=196)$, so that the $r_{\text {table }}$ is 0.1395 . based on the Table 2 which is the result of SPSS version 23 data processing, that all statement items from the variables of ease of shopping (X1), online customer review (X2) and perceptions of maslahah (X3) are valid,

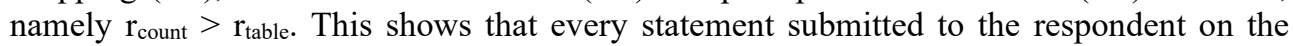
variable perception of maslahah is able to measure what the respondent wants. 


\section{$A I C \overline{I E B} \quad$ Annual International Conference \\ on Islamic Economics and Business, 2021}

Table 2. Validity test

\begin{tabular}{|c|c|c|c|c|}
\hline Variables & Statement items & $\mathbf{r}_{\text {count }}$ & $\mathbf{r}_{\text {table }}$ & Description \\
\hline \multirow{10}{*}{$\begin{array}{l}\text { Ease of shopping } \\
\text { (X1) }\end{array}$} & Item 1 & 0.607 & 0.1395 & Valid \\
\hline & Item 2 & 0.645 & 0.1395 & Valid \\
\hline & Item 3 & 0.483 & 0.1395 & Valid \\
\hline & Item 4 & 0.679 & 0.1395 & Valid \\
\hline & Item 5 & 0.644 & 0.1395 & Valid \\
\hline & Item 6 & 0.596 & 0.1395 & Valid \\
\hline & Item 7 & 0.659 & 0.1395 & Valid \\
\hline & Item 8 & 0.584 & 0.1395 & Valid \\
\hline & Item 9 & 0.662 & 0.1395 & Valid \\
\hline & Item 10 & 0.678 & 0.1395 & Valid \\
\hline \multirow{10}{*}{$\begin{array}{l}\text { Online customer } \\
\text { review (X2) }\end{array}$} & Item 1 & 0.625 & 0.1395 & Valid \\
\hline & Item 2 & 0.647 & 0.1395 & Valid \\
\hline & Item 3 & 0.633 & 0.1395 & Valid \\
\hline & Item 4 & 0.684 & 0.1395 & Valid \\
\hline & Item 5 & 0.658 & 0.1395 & Valid \\
\hline & Item 6 & 0.658 & 0.1395 & Valid \\
\hline & Item 7 & 0.552 & 0.1395 & Valid \\
\hline & Item 8 & 0.715 & 0.1395 & Valid \\
\hline & Item 9 & 0.679 & 0.1395 & Valid \\
\hline & Item 10 & 0.590 & 0.1395 & Valid \\
\hline \multirow{11}{*}{$\begin{array}{l}\text { Perceptions of } \\
\text { maslahah (X3) }\end{array}$} & Item 1 & 0.595 & 0.1395 & Valid \\
\hline & Item 2 & 0.535 & 0.1395 & Valid \\
\hline & Item 3 & 0.659 & 0.1395 & Valid \\
\hline & Item 4 & 0.638 & 0.1395 & Valid \\
\hline & Item 5 & 0.608 & 0.1395 & Valid \\
\hline & Item 6 & 0.060 & 0.1395 & Valid \\
\hline & Item 7 & 0.735 & 0.1395 & Valid \\
\hline & Item 8 & 0.789 & 0.1395 & Valid \\
\hline & Item 9 & 0.638 & 0.1395 & Valid \\
\hline & Item 10 & 0.704 & 0.1395 & Valid \\
\hline & Item 11 & 0.729 & 0.1395 & Valid \\
\hline \multirow{9}{*}{$\begin{array}{c}\text { Online shoppig } \\
\text { decision (Y) }\end{array}$} & Item 1 & 0.659 & 0.1395 & Valid \\
\hline & Item 2 & 0.590 & 0.1395 & Valid \\
\hline & Item 3 & 0.550 & 0.1395 & Valid \\
\hline & Item 4 & 0.692 & 0.1395 & Valid \\
\hline & Item 5 & 0.573 & 0.1395 & Valid \\
\hline & Item 6 & 0.685 & 0.1395 & Valid \\
\hline & Item 7 & 0.679 & 0.1395 & Valid \\
\hline & Item 8 & 0.722 & 0.1395 & Valid \\
\hline & Item 9 & 0.619 & 0.1395 & Valid \\
\hline
\end{tabular}

\subsection{Reliability Test}

Reliability is a measure that shows the extent to which the measurement results used remain consistent when two or more measurements are made on the same symptoms and with the same measuring instrument. Reliability refers to be consistency and stability of the results of a certain measurement scale (Hulu, V. T., \& Sinaga, 2019). The reliability of a variable construct is said to be good if it has a Cronbach's Alpha value $>0.60$. 
Table 3. Reliability test

\begin{tabular}{|c|c|c|}
\hline Variable & Cronbach's Alpha & Description \\
\hline Ease of shopping (X1) & 0.812 & Reliable \\
\hline $\begin{array}{c}\text { Online customer } \\
\text { review (X2) }\end{array}$ & 0.839 & Reliable \\
\hline $\begin{array}{c}\text { Perceptions of } \\
\text { maslahah (X3) }\end{array}$ & 0.871 & Reliable \\
\hline $\begin{array}{c}\text { Online shopping } \\
\text { decision (Y) }\end{array}$ & 0.812 & Reliable \\
\hline
\end{tabular}

\subsection{Classic Assumption Test}

\subsubsection{Normality test}

Normality test is a test to measure whether our data has normal distribution can be used in parametric statistics (Sujarweni, 2015). In this test, using the Kolmogorov-Smirnov formula, which compares the distribution of the data (which will be tested for normality) with the standard normal distribution. Residual data can be said to be normally distributed if the value of Sig. $>0.05$.

Table 4. Normality test results

One-Sample Kolmogorov-Smirnov Test

\begin{tabular}{|c|c|}
\hline Test Statistic & .060 \\
\hline Asymp. Sig. (2-tailed) & $.079^{\mathrm{c}}$ \\
\hline
\end{tabular}

a. Test distribution is Normal.

b. Calculated from data.

c. Lilliefors Significance Correction

\subsubsection{Linearity test}

The linearity test was carried out to see whether the model built was linear or not (Duli, 2019). If Devitation from linearity Sig $>0.05$ then there is a significant linear relationship between the independent variable and the dependent variable.

Table 5. Linearity test results

ANOVA Table

\begin{tabular}{|l|c|c|c|}
\hline \multirow{2}{*}{\multicolumn{1}{|c|}{ Variable }} & \multicolumn{2}{|c|}{ Devitation From Linearity } & \multirow{2}{*}{ Conclusion } \\
\cline { 2 - 3 } & F & Sig. & Linear \\
\hline Ease of shopping (X1) & 0.969 & 0.498 & Linear \\
\hline Online customer review (X2) & 1.306 & 0.188 & Linear \\
\hline Perceptions of maslahah (X3) & 1.302 & 0.179 & \\
\hline
\end{tabular}

\subsubsection{Heteroscedasticity test}

The heteroscedasticity test with Glejser SPSS basically aims to test whether in the regression model there is a difference in variance from the residual of one observation to another observation remains, the it is called homoscedasticity, and if they are different the it is called heteroscedasticity (Duli, 2019). 
Table 6. Glejser test results

Coefficient ${ }^{\mathrm{a}}$

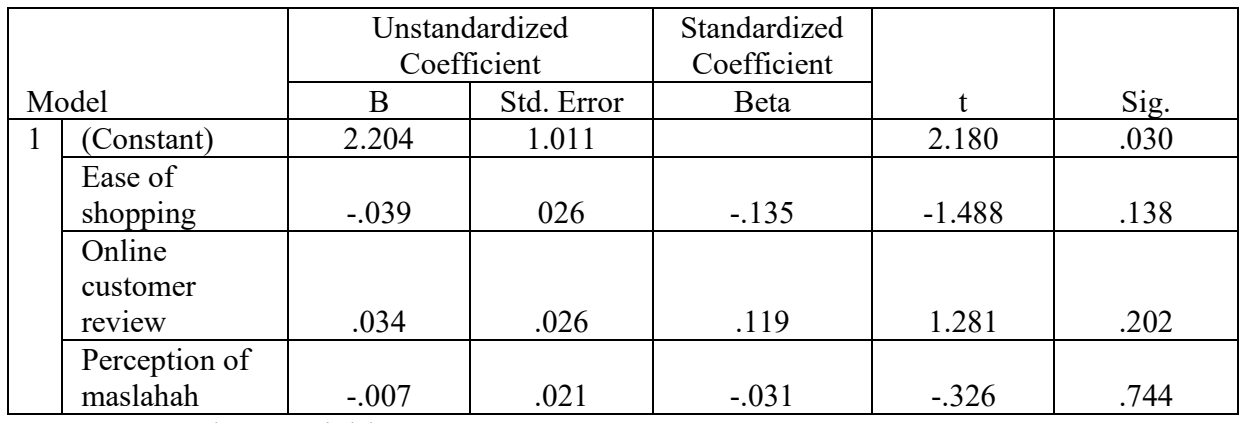

a. Dependent Variable: RES2

Based on the table of Glejser test results which show the value of Sig. ease of shopping (X1) is 0.138 , online customer review (X2) is 0.202 and the perception of maslahah (X3) is 0.74 , each of which is more than 0.05 . Means that the data does not occur heteroscedasticity or homoscedasticity occurs.

\subsubsection{Multicollinearity test}

Multicollinearity occurs in regression models that have more than one independent variable where there is a strong correlation between variables independent. A good model is one that does not experience multicollinearity (Wijaya, 2003). To find out whether or not there is a multicollinearity problem, can using the VIF (Variance Inflation Factory). If the VIF value is still less than 10 and the Tolerance Value is greater than 0.1 , the multicollinearity does not occur (Purwoto, 2010).

Table 7. Multicollinearity test results

\begin{tabular}{|c|c|c|}
\hline Variable & Tolerance Value & VIF \\
\hline Ease of shopping (X1) & 0.619 & 1.614 \\
\hline Online customer review (X2) & 0.589 & 1.698 \\
\hline Perceptions of maslahah (X3) & 0.549 & 1.832 \\
\hline
\end{tabular}

\subsection{Multiple Linear Regression Analysis}

Multiple linear regression is a linear regressionmodel that involves more than one independent variable (Ghodang \& Hantono, 2020). Multiple lineat regression analysis was used to learn more about the relationship between several independent variables and the dependent variable (Wanto, Anjar, 2020). The following are the results obtained from data processing:

Table 8. Multiple linear regression analysis

Coefficients $^{\mathrm{a}}$

\begin{tabular}{|c|c|c|c|c|c|c|}
\hline & \multirow[b]{2}{*}{ Model } & \multicolumn{2}{|c|}{$\begin{array}{c}\text { Unstandardized } \\
\text { Coefficients }\end{array}$} & \multirow{2}{*}{$\begin{array}{c}\begin{array}{c}\text { Standardized } \\
\text { Coefficients }\end{array} \\
\text { Beta } \\
\end{array}$} & \multirow[b]{2}{*}{$\mathrm{T}$} & \multirow[b]{2}{*}{ Sig. } \\
\hline & & $\mathrm{B}$ & Std. error & & & \\
\hline \multirow[t]{3}{*}{1} & (Constant) & 1.180 & 1.685 & & .700 & .485 \\
\hline & $\begin{array}{l}\text { Ease of } \\
\text { shopping }\end{array}$ & .223 & .043 & .239 & 5.168 & .000 \\
\hline & Online & .288 & .044 & .312 & 6.589 & .000 \\
\hline
\end{tabular}




\section{$A I \overline{I E B} \quad$ Annual International Conference \\ on Islamic Economics and Business, 2021}

\begin{tabular}{|l|l|r|r|r|r|r|}
\hline & $\begin{array}{l}\text { customer } \\
\text { review }\end{array}$ & & & & \\
\cline { 2 - 6 } & $\begin{array}{l}\text { Perceptions of } \\
\text { maslahah }\end{array}$ & .324 & .035 & .459 & 9.331 & .000 \\
\hline
\end{tabular}

a. Dependent Variable: Online shopping decision

Based on the results of regression test in table 8, the regression equation as follows:

$\mathrm{Y}=1.180+0.223 \mathrm{X}_{1}+0.288 \mathrm{X}_{2}+0.324 \mathrm{X}_{3}$

Description:

$\mathrm{Y}=$ Online shopping decision

$\mathrm{X} 1=$ Ease of shopping

$\mathrm{X} 2=$ Online customer review

$\mathrm{X} 3$ = Perceptions of maslahah

Interpretation of the regression model equation above, are

4.4.1 The constant is 1.180. This means that if the variable of ease of shopping (X1), online customer review (X2) and perceptions of maslahah (X3) are considered to be in a stable and constant position, then the online shopping decisioms score $(\mathrm{Y})$ by 1.180

4.4.2 The regression coefficient of $X 1$ is 0.223 , which means that if the ease score shopping (X1) increases by one unit, online shopping decision score $(\mathrm{Y})$ increases of 0.223 units with the assumption that $\mathrm{X} 2$ and $\mathrm{X} 3$ are consistent/fixed.

4.4.3 The $\mathrm{X} 2$ regression coefficient is 0.288 which means that if the online customer score review (X2) increased by one unit, online shopping decision score $(Y)$ increased of 0.228 units with the assumption that $\mathrm{X} 1$ and $\mathrm{X} 3$ are consistent/fixed.

4.4.4 The $\mathrm{X} 3$ regression coefficient is 0.324 which means that if the perception score is maslahah $(\mathrm{X} 3)$ increased by one unit, online shopping decision score $(\mathrm{Y})$ increased by 0.324 units assuming $\mathrm{X} 1$ and $\mathrm{X} 2$ were consistent/fixed Normality test

\subsection{Coefficient of Determination $\left(R^{2}\right)$}

The coefficient of determination $\left(\mathrm{R}^{2}\right)$ is used to measure how far the ability of the dependent variables. The value of the coefficient of determination $\left(\mathrm{R}^{2}\right)$ is between 0 and 1 . If the coefficient of determination is equal to 0 , then the independent variable has no effect on the dependent variable. If the magnitude of the coefficient of determination is towards number 1 , then the independent variable has a perfect effect on the dependent variable (Sujarweni, 2015). Following is the result of the coefficient of determination:

Table 9. Coefficient of determination $\left(\mathrm{R}^{2}\right)$

\section{Model Summary ${ }^{\mathrm{b}}$}

\begin{tabular}{|c|c|c|c|c|}
\hline Model & $\mathrm{R}$ & R Square & $\begin{array}{c}\text { Adjusted R } \\
\text { Square }\end{array}$ & $\begin{array}{c}\text { Std. Error of the } \\
\text { Estimate }\end{array}$ \\
\hline 1 & $.862^{\mathrm{a}}$ & .743 & .739 & 2.166 \\
\hline
\end{tabular}

a. Predictors: (Constant), ease of shopping, online customer review, perceptions of maslahah

b. Dependent variable: Online shopping decision 


\section{$A I C \overline{I E B} \quad$ Annual International Conference \\ on Islamic Economics and Business, 2021}

Based on table 8 above, it is known that the value of R Square or the coefficient of determination is 0.743 or $74.3 \%$. This shows that the influence of the convenience of shopping (X1), online customer review (X2) and perceptions of maslahah (X3) on online shopping decisions (Y) is $74.3 \%$, while the remaining $25.7 \%$ is influenced by other variables outside the variables that researched.

\subsection{Partial Test (T Test)}

$\mathrm{T}$ test is a test carried out to determine the relationship between variables partially independent of the dependent variable (Sujarweni, 2015).

4.6.1 Based on the results of tests carried out on the convenience of shopping variable (X1), it is obtained that tcount is 5,168 with ttable worth $=\mathrm{n}-\mathrm{k}-1(198-4-1=193)$ is 1,972 which means the value of tcount $>$ ttable and the value of Sig. of $0.000<0.05$. Means the ease of shopping online (X1) has a significant effect on online shopping decisions (Y).

4.6.2 Based on the results of tests conducted on the online customer variable review (X2) obtained tcount of 6.589 with ttable worth $=\mathrm{n}-\mathrm{k}-1(198-4-1=193)$ is 1.972 which means the value of tcount $>$ ttable and the value of Sig. of $0.000<0.05$. It means that online customer review (X2) has a significant effect on online shopping decisions (Y).

4.6.3 Based on the results of the tests carried out on the variable perception of maslahah (X3), it was obtained that tcount was 9.331 with ttable worth $=\mathrm{n}-\mathrm{k}-1(198-4-1=193)$ was 1.972 , which means the value of tcount $>$ ttable and the value of Sig. of $0.000<0.05$. It means that the perception of maslahah (X3) has a significant effect on online shopping decisions $(\mathrm{Y})$.

\subsection{Simultaneous Test (F Test)}

The F test is used to test the significance of the overall model or the independent variable simultaneously on the dependent variable (Ghozi dan Sunindyo, 2016). The criteria in the simultaneous F test include, if the value of Sig. $<0.05$ or Fcount $>$ Ftable, then $\mathrm{Ha}$ is accepted and $\mathrm{H} 0$ is rejected. If the value of Sig. $>0.05$ or Fcount $<$ Ftable, then Ha is rejected and $\mathrm{H} 0$ is accepted. Here are the results of the F test:

Table 10. F-test results

ANOVA $^{\mathrm{s}}$

\begin{tabular}{|l|l|r|r|r|r|r|}
\hline \multicolumn{2}{|c|}{} & \multicolumn{1}{l|}{$\begin{array}{l}\text { Sum of } \\
\text { Squares }\end{array}$} & df & $\begin{array}{l}\text { Mean } \\
\text { Square }\end{array}$ & F & \multicolumn{1}{l|}{ Sig. } \\
\hline \multirow{3}{*}{1} & Regressiom & 2633.378 & 3 & 877.793 & 187.146 & .00 \\
\cline { 2 - 7 } & Residual & 909.940 & 194 & 4.690 & & $0^{\mathrm{b}}$ \\
\cline { 2 - 8 } & Total & 3543.318 & 197 & & & \\
\hline
\end{tabular}

a. Dependent variable: online shopping decision

b. Predictors: (Constant), ease of shopping, online customer review, perceptions of maslahah

Based on the results of the F test, the $F_{\text {count }}$ value of 187.146 and the value of Sig. 0.000 .

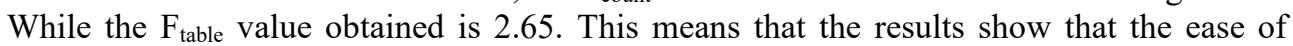


shopping (X1), online customer review (X2), and Perception of maslahah (X3) simultaneously affect online shopping decisions (Y).

\section{Conclusion}

\subsection{Ease of Shopping (X1) Affects Online Shopping Decisions (Y)}

The results of this study indicate a positive influence of the ease of shopping variable on online shopping decisions. This is based on the t-test (partial) for the ease of shopping variable obtained $t_{\text {count }}>t_{\text {table }}(5.168>1.972)$ which means the ease of shopping $(X 1)$ has a significant effect on online shopping decisions (Y). In addition, to prove that this research is significant, it can be done by looking at the value of Sig. of 0.000 or less than 0.05 which means that there is a significant influence of the online shopping convenience variable on online shopping decisions.

From this study, it can be seen that there is a positive influence between the ease of shopping on online shopping decisions. This means, the easier it is to shop, the bigger the decision to shop online. This is in accordance with the theory put forward by Ha \& Stoel in Dora Simões, that convenience is the main determinant of the acceptance and use of technology. This is also related to young consumers who tend to choose to shop online because it is easier to save time and goods purchased can be delivered on the same day (Pusparisa \& Ridhoi, 2020). Perceived ease of shopping affects consumers' intentions and decisions to shop online (Simões \& Filipe, 2019). Ease of shopping is felt when someone believes that it is not difficult to do shopping online by utilizing existing technology. This shows that someone who thinks that online shopping can be done easily will affect online shopping decisions.

These results are in line with the research conducted by Hamni Fadlilah Nasution with the results that there is a positive influence of convenience on online shopping decisions. It can be seen from the results of the $t$ (partial) test in the study, namely tcount of 3.180 and ttable of 1.972 or $t_{\text {count }}>t_{\text {table }}$ which means that ease of having an influence on online shopping decisions (Nasution, 2018). But contrary to Eko Yuliawan's research which states that convenience does not affect online shopping decisions, because when they shop online for the first time, prospective consumers will experience difficulties caused by consumer ignorance in the application of online transaction systems, because not all online businesses implement procedures. the same transaction (Yuliawan, 2018).

\subsection{Online Customer Review (X2) Affects Online Shopping Decisions (Y)}

The results of this study indicate that there is a positive influence of the online customer review variable on online shopping decisions. This is based on the t-test (partial) for the online customer review variable obtained $t_{\text {count }}>t_{\text {table }}(6.589>1.972)$ which means online customer review (X2) has a significant effect on online shopping decisions (Y). In addition, to prove that this research is significant, it can be done by looking at the value of Sig. of 0.000 or less than 0.05 which means that there is a significant influence of the online customer review variable on online shopping decisions.

This shows that the greater the consumer's attention to online customer review, the decision to shop online is getting better increase. The influence of online customer reviews is because these variables are a source of information about a product, and prospective consumers can learn about the product to be consumed from consumers who have already felt the benefits of the product and decide to continue purchasing. The results of this study prove that with online customer reviews, consumers have no trouble finding comparisons 
with similar products sold by other online sellers. This is in line with the theory put forward by Brickart, Schindler and Godes in Elvira Ismagilova that consumers rely more on online customer reviews because previous consumers are more relevant to potential consumers than the information provided by sellers (Ismagilova et al., 2017).

The results of this study are in line with the research of Pratiwi Arbaini, with the results of the Sig. of $0.000<0.05$ and $t_{\text {count }} 3.664>t_{\text {table }} 1.984$ which This means that online customer reviews have a positive and significant effect on online shopping decisions (Arbaini, 2020). However, this is contrary to the research conducted by Cucu Andita Widya $\mathrm{G}$ and Sulis Riptiono which stated that online consumer reviews have no influence on purchasing decisions because the reviews given by other consumers do not match what consumers need (Widya \& Riptiono, 2019).

\subsection{Perceptions of Maslahah (X3) Affects Online Shopping Decisions (Y)}

The results of this study indicate a positive influence of the variable perception of maslahah on online shopping decisions. This is based on the t-test (partial) for the variable perception of maslahah $t_{\text {count }}>t_{\text {table }}(9,331>1,972)$ which means that perception of maslahah $(X 3)$ has a significant effect on online shopping decisions $(\mathrm{Y})$. In addition, to prove that this research is significant, it can be done by looking at the value of Sig. 0.000 or less than 0.05 , which means that there is a significant influence of the variable perception of maslahah on online shopping decisions.

This states that the greater the consumer's attention to the perception of maslahah, the decision to shop online will increase, and vice versa if the perception of maslahah decreases, the decision to shop online will also decrease. The influence of the perception of maslahah can be because Muslim consumers feel the need to obtain benefits and blessings from the products they buy so that consumers can achieve maslahah optimally (Elvira, 2016). Because maslahah means all forms of goodness and must meet three conditions, namely halal, useful, and brings blessings (Sholihin, 2013). The results of this study are in line with the theory put forward which says that the fulfillment of needs is determined by the concept of maslahah (Suyanto, 2007).

The results of this study are in line with Rini Elvira's research with the results of Muslim consumers' perceptions of maslahah having a significant effect on consumption decisions limited to halal commodities at the alpha level of $1 \%$ or at the confidence level of $99 \%$. This is because the concept of maslahah contains benefits and blessings so as to encourage consumer attitudes which prioritizes the benefits aspect over the pleasure aspect (Elvira, 2016).

\subsection{Ease of Online Shopping (X1), Online Customer Reviews (X2), and Perception of Maslahah (X3) Simultaneously Have Significant Influence on Online Shopping Decisions $(\mathrm{Y})$}

Based on the results of the ANOVA study in table 9, it shows that the ease of shopping online, online customer reviews, and the perception of maslahah simultaneously have a significant influence on online shopping decisions. This can be seen from the $\mathrm{F}_{\text {count }}$ value of $187.146>\mathrm{F}_{\text {table }} 2.65$ with the value of Sig. $0.000<0.05$ so $\mathrm{Ha}$ is accepted and $\mathrm{H} 0$ is rejected. Which means, the ease of shopping online, online customer reviews, and perceptions of maslahah have a significant influence on online shopping decisions.

The value of $\mathrm{R}$ Square is 0.743 . The results of the coefficient of determination test or $\mathrm{R}^{2}$, which means that the independent variable affects the dependent variable by $74.3 \%$ and the remaining $25.7 \%$ is influenced by other variables not examined in this study. 


\section{$A \mathrm{IC} \quad$ Annual International Conference \\ on Islamic Economics and Business, 2021}

Consumer behavior is an activity that is closely related to the existence of a buying process, consumers carry out activities such as information search, research and evaluation of goods or services. When consumers decide to buy a product, consumers will think in advance about the goods they will consume starting from the price, model, shape, packaging, quality, function or use of the item, and so on (Firmansyah, 2019).

Consumers will seek and obtain product information by searching for product information through media such as reviews on youtube, reading online writings from people who have bought and consumed these products. For example, with the convenience of online shopping and online customer reviews, which will add to the attractiveness and make consumers feel that the product is beneficial when consumed so that consumers confidently decide to shopping online.

\subsection{Most Dominant Variable Analysis}

Based on the results of multiple linear regression analysis, the largest regression coefficient value is found in the variable perception of maslahah (by 0.324). That is, the variable perception of maslahah has the most influence compared to other variables. The coefficient owned by the maslahah perception variable is positive, which means that the maslahah perception variable is the main reason for the preference of Muslim students at UINSI and UMKT Samarinda to shop online. This shows that consumption behavior by UINSI and UMKT Samarinda students is in accordance with Islamic consumption behavior which is carried out not only to meet needs and achieve satisfaction, but also with the aim of achieving maslahah.ations should be centred and should be numbered with the number on the right-hand side.

\section{References}

Adam, M. (2018). Manajemen pemasaran jasa teori dan aplikasi. Salemba Empat.

Ahmad Musadik, S. H. S., \& Abdul Ghani Azmi, I. (2019). Impulse Buying Behaviour from Islamic Perspective: A Conceptual Paper. In Islamic Development Management. Islamic Development Management. https://doi.org/10.1007/978-981-13-7584-2_12

Aldeen, K. N., Ratih, I. S., \& Pertiwi, R. S. (2021). Cash waqf from the millennials' perspective: a case of Indonesia. ISRA International Journal of Islamic Finance.

Annisa, A. A. (2021). Islamic Financial Literacy Cycle in the Family. Indonesian Journal of Islamic Economics Research, 3(1).

Arbaini, P. (2020). Pengaruh Consumer Online Rating Dan Review Terhadap Keputusan Pembelian Pada Pengguna Marketplace Tokopedia. Jurnal Bisnis Dan Manajemen, 7(1), 25-33. https://doi.org/10.26905/jbm.v7i1.3897

Ardyanto, Heru Susilo, R. (2015). Pengaruh Kemudahan Dan Kepercayaan Menggunakan E-Commerce Terhadap Keputusan Pembelian Online (Survei Pada Konsumen www.petersaysdenim.com). Jurnal Administrasi Bisnis S1 Universitas Brawijaya, 22(1), 85897.

Chalil, Z. F. (2009). Pemerataan Distribusi Kekayaan Dalam Ekonomi Islam: Khazanah Ekonomi Syariah. Erlangga.

Darics, E. (2016). The Discourse of Online Consumer Reviews. In English for Specific Purposes (Vol. 42). Bloomsbury Publishing. https://doi.org/10.1016/j.esp.2015.10.003

Davis, F. D. (1989). Perceived usefulness, perceived ease of use, and user acceptance of information technology. MIS Quarterly: Management Information Systems, 13(3), 319-339. https://doi.org/10.2307/249008

Dr. Moh. Mufid, Lc., M. H. . (2018). Ushul Fiqh Ekonomi dan Keuangan Kontemporer. 


\section{$A \mathrm{ICB}$ Annual International Conference \\ on Islamic Economics and Business, 2021}

Prenadamedia. http://idr.uin-antasari.ac.id/15968/3/Buku Ushul Fiqih Ekonomi Keuangan Syariah.pdf

Duli, N. (2019). Metodologi Penelitian Kuantitatif: Beberapa Konsep Dasar Untun Penulisan Skripsi dan Analisis Data dengan SPSS. Deepublish.

Elvira, R. (2016). Pengaruh Persepsi Konsumen Muslim Tentang Maslahah Terhadap Keputusan Konsumsi Terbatas Hanya Pada Komoditas Halal (Studi: Mahasiswa Fakultas Syariah dan Ekonomi Islam Tahun 2015). Manhaj, 04(02), 177-187.

Fernandes, S., Venkatesh, V. G., Panda, R., \& Shi, Y. (2021). Measurement Of Factors Influencing Online Shopper Buying Decisions: A Scale Development And Validation. Journal of Retailing and Consumer Services, 59(February 2020), 102394. https://doi.org/10.1016/j.jretconser.2020.102394

Firmansyah, M. A. (2019). Perilaku Konsumen (Sikap dan Pemasaran). Deepublish.

Frick, V., \& Matthies, E. (2020). Everything Is Just A Click Away. Online Shopping Efficiency And Consumption Levels In Three Consumption Domains. Sustainable Production and Consumption, 23, 212-223. https://doi.org/10.1016/j.spc.2020.05.002

Frida, C. V. O. (2020). Ekonomi Syariah: Pengantar Ekonomi Islam. e-books Gramedia Digital.

https://books.google.com/books?hl=en\&lr=\&id=tq7_DwAAQBAJ\&oi=fnd\&pg=PA1 $\& d q=$ ketimpangan+pertumbuhan+ekonomi+kebijakan+pemerintah+inovasi + dan + keu nggulan+absolut+dan+komparatif+suatu+negara\&ots=2mrxKZtpTo\&sig=_yu7xD5a MCCbwupGZSGxDj9hJcs

Ghodang, H., \& Hantono. (2020). Metodologi Penelitian Kuantitatif (Konsep Dasar dan Aplikasi Analisis Regresi dan Jalur dengan SPSS). Penerbit Mitra Grup.

Ghozi dan Sunindyo. (2016). Statistik Deskriptif Untuk Ekonomi. In Statistik Deskriptif Untuk Ekonomi. Deepublish.

Hulu, V. T., \& Sinaga, T. . (2019). Analisis Data Statistik Parametrik Aplikasi SPSS dan STATCAL, Yayasan Kita Menulis, Medan. Imam.

Indrasari, M. (2019). Pemasaran dan Kepuasan Pelanggan. Unitomo.

Ismagilova, E., Dwivedi, Y. K., Slade, E., \& Williams, M. D. (2017). Electronic Word of Mouth (eWOM) in the Marketing Context. In SpringerBriefs in Business. https://doi.org/10.1007/978-3-319-52459-7

Jain, P. K., Yekun, E. A., Pamula, R., \& Srivastava, G. (2021). Consumer recommendation prediction in online reviews using Cuckoo optimized machine learning models. Computers and Electrical Engineering, 95(May), 107397. https://doi.org/10.1016/j.compeleceng.2021.107397

Khan, S., Haleem, A., \& Khan, M. I. (2020). Risk management in Halal supply chain: an integrated fuzzy Delphi and DEMATEL approach. Journal of Modelling in Management, 16(1), 172-214. https://doi.org/10.1108/JM2-09-2019-0228

Mulyati, Y., \& Gesitera, G. (2020). Pengaruh Online Customer Review terhadap Purchase Intention dengan Trust sebagai Intervening pada Toko Online Bukalapak di Kota Padang. Jurnal Maksipreneur: Manajemen, Koperasi, Dan Entrepreneurship, 9(2), 173. https://doi.org/10.30588/jmp.v9i2.538

Nasution, H. F. (2018). Pengaruh Kemudahan Dan Harga Terhadap Keputusan Pembelian Produk Pakaian Secara Online (Studi Kasus Mahasiswa Belanja Online Pada FEBI IAIN Padangsidimpuan). At-Tijaroh: Jurnal Ilmu Manajemen Dan Bisnis Islam, 4(1), 26. https://doi.org/10.24952/tijaroh.v4i1.1082

Purwoto, A. (2010). Panduan Labolatorium Statistik Inferensial. Grasindo.

Pusparisa, Y., \& Ridhoi, M. A. (2020). Mayoritas Anak Muda Berbelanja Di E-Commerce Untuk Hemat Waktu By Katadata. Databoks.Katadata.Co.Id, datapublish. https://databoks.katadata.co.id/datapublish/2020/11/04/mayoritas-anak-mudaberbelanja-di-e-commerce-untuk-hemat-waktu 


\section{$A \mathrm{IC} \quad$ Annual International Conference \\ on Islamic Economics and Business, 2021}

Rose, S., Hair, N., \& Clark, M. (2011). Online Customer Experience: A Review of the Business-to-Consumer Online Purchase Context. International Journal of Management Reviews, 13(1), 24-39. https://doi.org/10.1111/j.14682370.2010.00280.x

Sholihin, A. I. (2013). Buku pintar ekonomi syariah. In 2013. Gramedi Pustaka utama. https://books.google.co.id/books?hl=en\&lr=\&id=3F5nDwAAQBAJ\&oi=fnd\&pg=PP1 $\& d q=$ sholihin+2013\&ots=IzGAPUzXo2\&sig=dTJkIsFSjulYMKRzmS5xZeFT75M\&r edir_esc $=\mathrm{y} \# \mathrm{v}=$ onepage $\& \mathrm{q}=$ sholihin

2013\&f=false\%0Ahttps://books.google.co.id/books?hl=id\&lr=\&id=3F5nDwAAQBAJ \&oi $=$ fnd\&pg $=\mathrm{P}$

Simões, D., \& Filipe, S. (2019). Smart marketing with the Internet of Things. In Smart Marketing With the Internet of Things. IGI Global. http://services.igiglobal.com/resolvedoi/resolve.aspx?doi=10.4018/978-1-5225-5763-0

Sujarweni, W. (2015). Metodologi Penelitian - Bisnis dan Ekonomi. In Metodologi Penelitian. Pustaka Baru Press.

Suyanto, M. (2007). Marketing Strategy Top Brand Indoesia. Yogyakarta. Penerbit Andi Offset.

Wanto, Anjar, D. (2020). Data Mining: Algoritma dan Implementasi - Books. In Yayasan kita menulis. Andi Publishing. https://books.google.co.id/books?id=AtcCEAAAQBAJ\&dq=buku+data+mining+dan+ teks+mining \&lr=\&hl=id\&source=gbs_navlinks_s

Widya, C. A., \& Riptiono, S. (2019). Pengaruh Online Consumer Review Dan Viral Marketing Terhadap Keputusan Pembelian Dengan Consumer Trust Sebagai Intervening (Studi Pada Pengguna Instagram Di 1 Kecamatan Kebumen). Jurnal Ilmiah Mahasiswa Manajemen, Bisnis Dan Akuntansi (JIMMBA), 1(1), 76-84. https://doi.org/10.32639/jimmba.v1i1.392

Wijaya, D. (2003). Analisis Regresi 1 Analisis Regresi. Elex Media Komputindo.

WiScicka-Fernando, M. (2021). The use of mobile technologies in online shopping during the Covid-19 pandemic - An empirical study. Procedia Computer Science, 192, 34133422. https://doi.org/10.1016/j.procs.2021.09.114

Y.B., A. (2010). Sukses Bisnis Toko Online Trik Melipatgandakan Pasar Untuk Meraup Untung Lebih Besar. Gramedia Pustaka Utama. https://books.google.co.id/books?id=LEbAUpoGCsgC\&printsec=frontcover\&hl=id\#v $=$ onepage $\& \mathrm{q} \& \mathrm{f}=\mathrm{false}$

Yuliawan, E. (2018). Analisis Pengaruh Faktor Kepercayaan, Kemudahan Dan Kualias Layanan Terhadap Keputusan Pembelian Pada Online Shop Zalora Indonesia (Studi Pada Mahasiswa Program Studi Manajemen STIE Mikroskil Medan). Optimal: Jurnal Ekonomi Dan Kewirausahaan, 12(1), 34-49. https://doi.org/10.33558/optimal.v12i1.1016

Yuswohady. (2012). Consumer 3000 - Revoluasi Konsumen Kelas Menengah Indonesia. Gramedia Pustaka Utama. 